Marquette University

e-Publications@Marquette

$11-2009$

\title{
The Effects of Intralayer Metal Composition of Layered Double Hydroxides on Glass Transition, Dispersion, Thermal and Fire Properties of Their PMMA Nanocomposites
}

\author{
Charles Manzi-Nshuti \\ Marquette University \\ Dan Chen \\ Hunan Normal University \\ Shengpei Su \\ Hunan Normal University
}

Charles A. Wilkie

Marquette University, charles.wilkie@marquette.edu

Follow this and additional works at: https://epublications.marquette.edu/chem_fac

Part of the Chemistry Commons

\section{Recommended Citation}

Manzi-Nshuti, Charles; Chen, Dan; Su, Shengpei; and Wilkie, Charles A., "The Effects of Intralayer Metal Composition of Layered Double Hydroxides on Glass Transition, Dispersion, Thermal and Fire Properties of Their PMMA Nanocomposites" (2009). Chemistry Faculty Research and Publications. 20.

https://epublications.marquette.edu/chem_fac/20 


\title{
The Effects of Intralayer Metal Composition of Layered Double Hydroxides on Glass Transition, Dispersion, Thermal and Fire Properties of their PMMA Nanocomposites
}

\author{
Charles Manzi-Nshuti \\ Department of Chemistry and Fire Retardant Research Facility, \\ Marquette University \\ Milwaukee, WI \\ Dan Chen \\ College of Chemistry and Chemical Engineering, Hunan Normal \\ University, Changsha, Hunan 410081 \\ People's Republic of China \\ Shengpei Su \\ College of Chemistry and Chemical Engineering, Hunan Normal \\ University, Changsha, Hunan 410081 \\ People's Republic of China \\ Charles A. Wilkie \\ Department of Chemistry and Fire Retardant Research Facility, \\ Marquette University \\ Milwaukee, WI
}


Abstract: A series of aluminum-containing layered double hydroxides (LDHs), containing $\mathrm{Mg}, \mathrm{Ca}, \mathrm{Co}, \mathrm{Ni}, \mathrm{Cu}$ and $\mathrm{Zn}$ as the divalent metals, have been prepared by the co-precipitation method and used to prepare nanocomposites of PMMA by in situ bulk polymerization. The additives were characterized by Fourier transform infrared spectroscopy, X-ray diffraction spectroscopy (XRD) and thermogravimetric analysis while the polymer composites were characterized by XRD, transmission electron microscopy, differential scanning calorimetry and cone calorimetry. Polymerization of methyl methacrylate in the presence of these undecenoate LDHs results in composites with enhanced thermal stability. The glass transition temperatures of the composites and the pristine polymers are found to be around $110 \mathrm{C}$; this suggests that the presence of these additives has little effect on the polymer. It is found that the additive composition and the dispersion state of LDHs agglomerates in the polymer matrix influence the fire properties of composites as measured by cone calorimetry.

\section{Introduction}

Recently, clay/polymer nanocomposites have attracted considerable interest as the clays are used as reinforcements of polymeric materials [1-3]. Clay/polymer nanocomposites often have properties that are dramatically different from those of the polymer alone with unique improvements in mechanical strength [4], thermal stability [5], flammability [6] and gas permeability [7]. The compatibility of the clay between the polymer and the clay is crucial for the formation of well-dispersed nanocomposites [6].

Until now, however, the work on polymer/clay systems have mainly focused on montmorillonite-type layered silicate whose layers have a relatively low charge density and from which montmorillonitetype layered silicate/polymer nanocomposites can be easily obtained [8-11]. Recently, there has been a growing interest in the preparation of other layered nanomaterials, like the layered double hydroxides (LDHs).

LDHs or hydrotalcite-like materials [12-14] are a class of anionic clays whose general formula is $\left[M(\mathrm{II})_{1-\mathrm{x}} \mathrm{M}(\mathrm{III})_{\mathrm{x}}(\mathrm{OH})_{2}\right]^{\mathrm{x}+}\left[\mathrm{A}_{\mathrm{x} / \mathrm{n}^{\mathrm{n}}} \bullet\right.$ $\left.\mathrm{mH}_{2} \mathrm{O}\right]^{\mathrm{x}}$, where $\mathrm{M}(\mathrm{II})$ and $\mathrm{M}(\mathrm{III})$ represent divalent and trivalent metal

Thermochimica Acta, Vol. 495, (2009): pg. 63-71. DOI. This article is (C) Elsevier and permission has been granted for this version to appear in e-Publications@Marquette. Elsevier does not grant permission for this article to be further copied/distributed or hosted elsewhere without the express permission from Elsevier. 
cations, respectively. The interlayer anion $\left(A^{n-}\right)$ may be varied over a wide range and the value of the stoichiometric coefficient $(x)$ should be between 0.2 and 0.33 [15].

Poly(methyl methacrylate) (PMMA) is an optically clear amorphous thermoplastic. It is widely used as a substitute for inorganic glass, because it shows higher impact strength and undergoes ductile rather than brittle fracture. It has favorable processing conditions, and a wide range of additives have been shown to further improve its properties [16].

Wang et al. prepared disorderly exfoliated LDHs/PMMA nanocomposites by in situ polymerization and observed enhancement of the decomposition temperatures and the glass transition temperature compared to pristine PMMA [17]. Bao et al. reported an enhancement in tensile strength, Young's modulus, and an increase of the glass transition temperature of the PVC/LDH nanocomposites relative to those of pristine PVC [18].

Qu et al. successfully synthesized exfoliated LDHs/PE-g-MA [19] and LDHs/LLDPE [20] nanocomposites by refluxing the LDH in a xylene solution of PE-g-MA and LLDPE, respectively. In earlier work from this laboratory [21], undecenoate-LDHs of $\mathrm{ZnAl}, \mathrm{CoAl}$ and NiAl were found to greatly enhance the thermal stability of melt blended PMMA while the cobalt-rich LDH at $10 \%$ loading in PMMA gave a $41 \%$ reduction in peak heat release rate (PHRR) relative to the pristine polymer. Also, good dispersion and enhancement of both fire and thermal properties were obtained for a combination of a series of alkyl carboxylatemodified LDHs with PMMA [22]. The initial work on using LDHs to enhance fire retardancy was carried out by Zamarrano et al., who found significant fire retardant effects in epoxy resins [23].

The effect of the nanofillers in polymer composites on the glass transition behavior of the polymer matrix has been studied. In some cases, increases in the glass transition temperature $\left(T_{\mathrm{g}}\right)$ have been reported $[24,25]$ while in other cases, decreases in $T_{g}$ are observed [26]. Molecular dynamics simulations of the polymer melts in the presence of nanoparticles have shown that the dynamics of the

Thermochimica Acta, Vol. 495, (2009): pg. 63-71. DOI. This article is (C) Elsevier and permission has been granted for this version to appear in e-Publications@Marquette. Elsevier does not grant permission for this article to be further copied/distributed or hosted elsewhere without the express permission from Elsevier. 
polymer melts can be influenced by the polymer-nanoparticle interactions [27].

Normally, an attractive polymer-filler interaction should suppress polymer motion, and then, an increase in $T_{\mathrm{g}}$ is expected in nanocomposites with good filler-polymer compatibility [28].

In this investigation, a series of undecenoate-containing LDHs of $\mathrm{ZnAl}, \mathrm{MgAl}, \mathrm{CaAl}, \mathrm{NiAl}, \mathrm{CoAl}$ and $\mathrm{CuAl}$ have been prepared and characterized. The effect of these LDHs on the glass transition, dispersion, thermal and fire properties of their PMMA composites are evaluated.

\section{Experimental}

\subsection{Materials}

Methyl methacrylate (MMA), benzoyl peroxide, zinc nitrate hexahydrate $(98 \%)$, cobalt(II) nitrate hexahydrate $(98 \%)$, calcium nitrate tetrahydrate (ACS reagent), magnesium nitrate hexahydrate (99\%), copper(II) nitrate hydrate (98\%), and aluminum nitrate nonahydrate (98\%) were obtained from Aldrich Chemical Co. Nickel(II) nitrate hexahydrate (99\%), 10-undecenoic acid (99\%), and sodium hydroxide, extra pure pellets, were purchased from Acros Organics. All chemicals were used without further purification. MMA monomer was passed through an inhibitor remover column before use.

\subsection{Preparation of $L D H s$}

The preparation and characterization of undecenoate-containing LDHs have been previously described [29]; the co-precipitation method is used and this strategy involves addition of an $\mathrm{M}^{\mathrm{II}} / \mathrm{M}^{\mathrm{III}}$ metal salt solution to a basic solution of the desired anions under nitrogen atmosphere to exclude $\mathrm{CO}_{2}$ which would lead to the formation of carbonate-LDHs [30]. 


\subsection{Preparation of LDHs/PMMA nanocomposites}

The PMMA/LDHs nanocomposites were prepared as follow: the appropriate LDH loading was combined with MMA, total weight $140 \mathrm{~g}$, in a $400 \mathrm{ml}$ beaker covered with aluminum foil, and the mixture was stirred vigorously for 1 day. Then, the initiator, $0.1 \%$ BPO was added, and the mixture was heated to $70^{\circ} \mathrm{C}$ until viscous. The viscous mixture was then heated to $100^{\circ} \mathrm{C}$ for $24 \mathrm{~h}$ and $120^{\circ} \mathrm{C}$ for $3 \mathrm{~h}$ to yield the LDH/PMMA nanocomposites. Finally, the polymer was placed overnight in a vacuum oven at $100{ }^{\circ} \mathrm{C}$ to remove unreacted monomer. For the two types of LDH composites prepared in this study, the LDH loadings used with PMMA were 3 and $6 \%$.

\subsection{Glass transition temperature, $T_{g}$ and molecular weight measurements}

The glass transition temperature $\left(T_{\mathrm{g}}\right)$ of the pure polymers and various PMMA/LDH composites were characterized with a differential scanning calorimeter (DSC822 Mettler Toledo using a FRS5 ceramic sensor). All samples were subjected to the following heating/cooling profile: the sample was heated from 50 to $130^{\circ} \mathrm{C}$ at $20^{\circ} \mathrm{C} / \mathrm{min}$ and cooled at $20^{\circ} \mathrm{C} / \mathrm{min}$ from 130 back to $50^{\circ} \mathrm{C}$. Then, the sample was maintained for $50 \mathrm{~s}$ at $50{ }^{\circ} \mathrm{C}$, and then reheated from 50 to $170{ }^{\circ} \mathrm{C}$ to obtain the second heat-flow result. From the step change of the reversible heat flow of the second heating, $T_{\mathrm{g}}$ was determined. Temperature in the DSC is reproducible to $\pm 0.5^{\circ} \mathrm{C}$.

The molecular weight of PMMA and PMMA/LDH composites were obtained from viscosity data. PMMA/6\%LDH samples were extracted for 4 days with acetone in a Soxhlet apparatus to dissolve the polymer, leaving behind the $\mathrm{LDH}$, and the polymer was dried in air (12 $\mathrm{h})$ and then in a vacuum oven at $80^{\circ} \mathrm{C}(12 \mathrm{~h})$. The results are an average of three determinations, and the Mark-Houwink constants were obtained from published data [31].

To investigate the effect of the solvent on the LDH alone, the undecenoate-LDHs were also extracted with acetone for 2 days and the collected powder was dried at room temperature and then in a vacuum oven at $60^{\circ} \mathrm{C}$ for $12 \mathrm{~h}$. X-ray diffraction (XRD),

Thermochimica Acta, Vol. 495, (2009): pg. 63-71. DOI. This article is (C) Elsevier and permission has been granted for this version to appear in e-Publications@Marquette. Elsevier does not grant permission for this article to be further copied/distributed or hosted elsewhere without the express permission from Elsevier. 
thermogravimetric analysis (TGA), and Fourier transform infrared spectroscopy (FTIR) of the LDH after extraction were obtained and compared with the original samples.

\subsection{Characterization of $L D H$ and PMMA/LDH systems}

Fourier transform infrared spectroscopy (FT-IR) of the solid materials was obtained on a Bruker Tensor 27 series, with a Pike Miracle ATR accessory using a ZnSe crystal.

TGA was performed on a Netzsch TG 209 F1 instrument at the $15 \mathrm{mg}$ scale under a flowing air atmosphere at a scan rate of 20 ${ }^{\circ} \mathrm{C} / \mathrm{min}$. Temperature is reproducible to $\pm 1{ }^{\circ} \mathrm{C}$ and mass to $\pm 0.2 \%$. TGA experiments were done in duplicate and the averages are reported. XRD data was obtained using a Rigaku Miniflex II desktop Xray diffractometer; data acquisition was performed using a scan speed

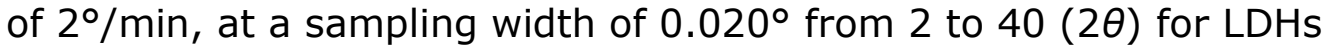
and 2 to $10(2 \theta)$ for polymeric samples. Bright field transmission electron microscopy (TEM) used a JEOL 1230 MSC SI033 microscope equipped with a Tietz F224 digital camera, operated at an accelerating voltage of $100 \mathrm{kV}$. Cone calorimeter measurements were performed on an Atlas CONE-2 according to ASTM E 1354 at an incident flux of 50 $\mathrm{kW} / \mathrm{m}^{2}$, using a cone shaped heater; the exhaust flow was set at 24 $\mathrm{L} / \mathrm{s}$. The specimens for cone calorimetry were prepared by the compression molding of the sample (about $30 \mathrm{~g}$ ) into $3 \mathrm{~mm} \times 100 \mathrm{~mm}$ $\times 100 \mathrm{~mm}$ square plaques. Typical results from cone calorimetry are reproducible to within about $\pm 10 \%$; these uncertainties are based on many runs in which thousands of samples have been combusted [32].

\section{Results and discussion}

\subsection{Characterization of the $M^{I I} / A l / u n d e c e n o a t e ~ L D H$ series}

\subsubsection{XRD characterization of the $M^{I I} / A l /$ undecenoate $L D H$ series}

XRD traces of the $\mathrm{M}^{\mathrm{II}} / \mathrm{Al} /$ undecenoate $\mathrm{LDH}$ series where the divalent metal cations were varied are shown in Fig. 1. All the

Thermochimica Acta, Vol. 495, (2009): pg. 63-71. DOI. This article is (C) Elsevier and permission has been granted for this version to appear in e-Publications@Marquette. Elsevier does not grant permission for this article to be further copied/distributed or hosted elsewhere without the express permission from Elsevier. 
diffraction peaks are in good agreement with layered structures; the diffraction peaks of calcium aluminum undecenoate $(\mathrm{CaAl})$ are sharper and symmetric relative to the others which means that the layers of this particular LDH are more pronounced. The interlayer spacings of these LDHs range between 2.3 and $3.2 \mathrm{~nm}$ as shown in Table 1 . The Scherrer equation, which evaluates peak broadening, can be used to describe the crystallite size, assuming that other factors, such as swollen ends or poor alignment, do not interfere. CaAl has the largest crystallite size of about $63 \mathrm{~nm}$, which correspond to about 19-20 stacked layers while MgAl has the lowest crystallite size of $9 \mathrm{~nm}$ (corresponding to about 3-4 stacked layers), calculated using the Scherrer equation.

\subsubsection{ATR-IR characterization of the MII/Al/undecenoate $L D H$ series}

The FT-IR spectra of the six layered materials synthesized in this study are provided in Fig. 2; assignments of the various bands correlate with the MgAl-undecenoate LDH reported by Wang et al. [34]. The bands in the range of $910-1000 \mathrm{~cm}^{-1}$ correspond to the outof-plane $\mathrm{C}-\mathrm{H}$ bending vibrations. The strong absorption peaks in the range of $1600-1430 \mathrm{~cm}^{-1}$ are assigned to the asymmetric and symmetric stretching vibrations, respectively, of $\mathrm{RCOO}^{-}$[34]. The shoulder observed around $1360 \mathrm{~cm}^{-1}$ for $\mathrm{ZnAl}$ is assigned to minor contamination of carbonate anions in this LDH while the presence of two bands for CaAl LDH in the 1500-1600 region may suggest the presence of hydrogen bonded carboxylic acid in the gallery of this LDH along with the charge balancing undecenoate anions. The $\mathrm{C}=\mathrm{C}$ stretching vibration is around $1640 \mathrm{~cm}^{-1}$ and a very small shoulder corresponding to the $\mathrm{C}-\mathrm{H}$ stretching vibration for the $\mathrm{sp}^{2}$ carbon of the 10 -undecenoate anion is located around $3080 \mathrm{~cm}^{-1}$ [35]. The strong and broad absorption peak near $3400 \mathrm{~cm}^{-1}$ is attributed to the $-\mathrm{OH}$ group in both the LDH sheets and the interlayer water molecules [36]. All these spectra support the fact that the undecenoate anion has been intercalated in the galleries of all six LDHs.

Characterization of undecenoate-LDHs after extraction with acetone in a Soxhlet apparatus for 2 days used FT-IR. As seen in Fig. 3 , there is a strong similarity between the LDHs before and after

Thermochimica Acta, Vol. 495, (2009): pg. 63-71. DOI. This article is (C) Elsevier and permission has been granted for this version to appear in e-Publications@Marquette. Elsevier does not grant permission for this article to be further copied/distributed or hosted elsewhere without the express permission from Elsevier. 
extraction with acetone for 2 days. CoAI LDH and ZnAI LDH spectra show a carbonate band around $1360 \mathrm{~cm}^{-1}$, in addition to the expected bands of undecenoate moiety, which indicate that small contamination of this anion occurred during extraction. Other than exposure to $\mathrm{CO}_{2}$ with the formation of an LDH carbonate, extraction of the LDH, and hence also the polymer-LDH composites, has no effect on the LDH as ascertained by FTIR.

\subsection{TGA behavior of the undecenoate-LDH series}

Fig. 4 presents the TGA curves of the various LDHs studied in this work while Fig. 5 shows their TGA profiles after washing with acetone in a Soxhlet apparatus for 2 days. The TGA profiles of all six of the undecenoate LDHs show multiple events in the temperature range 80-500 ${ }^{\circ} \mathrm{C}$, as shown in Fig. 4. Typically, the mass loss below $150{ }^{\circ} \mathrm{C}$ is ascribed to the loss of loosely bound gallery water followed by partial dehydroxylation of the layers up to $200^{\circ} \mathrm{C}$. The multiple events in the temperature regime $200-500{ }^{\circ} \mathrm{C}$ are associated with the decomposition of the LDH organic moieties [37]. At the end of TGA experiment, the residues collected range from $32 \%$ for $\mathrm{CaAI} \mathrm{LDH}$ to $53 \%$ for ZnAl LDH.

Fig. 5 shows the TGA profiles of the LDH before and after washing with acetone in a Soxhlet apparatus for 2 days. The similarities between the TGA curves of the undecenoate-LDHs before and after washing with acetone suggest that only an insignificant amount of physisorbed water is present in the LDH, considering the fact that the two profiles overlap in the region $30-200{ }^{\circ} \mathrm{C}$. Also, since the inorganic contents are the same at $800{ }^{\circ} \mathrm{C}$, one can postulate that the LDHs do not contain any significant amount of unbound organic moieties which would decrease the inorganic content of the LDHs in TGA experiments. As will be discussed in later sections, the similarity in the TGA profiles of both the washed and unwashed LDHs also assures that when polymer/LDH composites are extracted with acetone in a Soxhlet apparatus, almost all LDH is retained and one can further analyze the resulting polymer in the absence of the LDH.

Thermochimica Acta, Vol. 495, (2009): pg. 63-71. DOI. This article is (C) Elsevier and permission has been granted for this version to appear in e-Publications@Marquette. Elsevier does not grant permission for this article to be further copied/distributed or hosted elsewhere without the express permission from Elsevier. 
NOT THE PUBLISHED VERSION; this is the author's final, peer-reviewed manuscript. The published version may be accessed by following the link in the citation at the bottom of the page.

\subsection{Morphological studies of PMMA/LDH systems}

The XRD patterns of the PMMA/LDHs are shown along with those of the LDH precursors (Fig. 6). For the XRD traces of PMMA/NiAl and PMMA/ZnAl systems at higher LDH loading (6\%), the main diffraction peaks of the organo-LDH are still observed after polymerization, or in other words, no significant change in d-spacing between the organo-LDH and the composites is observed, an indication of the formation of an immiscible systems. All other composites, however, do not show any diffraction peaks after the polymerization process. The absence of the diffraction peaks may mean that exfoliated nanocomposites or disordered systems are obtained; TEM images are required and were obtained to clarify the type of dispersion of these systems. The TEM images are shown in Figs. 7 and 8. TEM provides direct imaging of the nanocomposite structure and filler dispersion, allowing good assessment of the dispersion of the nanofiller. The TEM image at low magnification is used to determine the dispersion of the layered material in the polymer while the higher magnification image enables the description of the material as intercalated or exfoliated.

Fig. 7 provides the TEM images of these systems at lower magnification for PMMA/NiAl (A), MgAl (B), CoAl (C), CaAl (D) and CuAl (E). Except for PMMA/CoAl (C) where relatively good dispersion is observed, the other systems show poor dispersion, with tactoids of different sizes present in the PMMA matrix. The shapes and sizes of these tactoids, however, are quite different. NiAl (A) shows a large number of fairly small particles while for MgAl (B) much larger particles are seen. CoAl (C) is similar to what is seen for MgAl while CaAl shows the smallest particle size. Each LDH has a different effect on the distribution of particles in the polymer.

The higher magnification images (Fig. 8) allow one to visualize the length of the LDH layers. With PMMA/MgAl (B), layers of around $200 \mathrm{~nm}$ in length are observed while in the high magnification image of PMMA/CoAl (C), layers of various sizes (from 50 to $100 \mathrm{~nm}$ in length) are observed. It is clear that controlling the crystallite size and crystallite size distribution of these LDH additives is going to be a key

Thermochimica Acta, Vol. 495, (2009): pg. 63-71. DOI. This article is (C) Elsevier and permission has been granted for this version to appear in e-Publications@Marquette. Elsevier does not grant permission for this article to be further copied/distributed or hosted elsewhere without the express permission from Elsevier. 
if these additives are used to improve the mechanical properties of the polymer composites. The small particles of various sizes observed with PMMA/CuAl samples were expected as the samples changed color from green to olive-brown, possibly due to decomposition of the LDH during preparation; the formation of reduced copper species may also occur. The TEM image of the most crystallized LDH, CaAl, shows agglomerates of various sizes (50-500 nm). PMMA/NiAl samples also show agglomerates, but in this instance, they are fairly well distributed in the polymeric matrix. Previous work from these laboratories showed a good correlation between the morphology of MMT composites and fire properties $[6,11]$. The morphology of PMMA/CaAl and PMMA/NiAl samples however reveal a new and interesting behavior of LDH particles where agglomerates are probably formed during polymerization. The high layer charge densities probably explain the difficulty in exfoliating the LDH layers; more work is underway to investigate how to ensure layer separation during polymerization.

\subsection{Molecular Weight of solvent extractable polymer- LDH nanocomposites}

In order to obtain the molecular weight of PMMA in the LDH/PMMA composites, the solvent extraction method was employed. The molecular weights determined by viscosity data are shown in Table 2. The various LDH additives all increase the molecular weight of the PMMA composites compared to that prepared in the absence of an $\mathrm{LDH}$; CaAl gives the highest $\mathrm{Mw}$, about twice that in the absence of an $\mathrm{LDH}$, but MgAl and NiAl are only a little larger than pristine PMMA. These results should be compared to reported data where the influence of additive type on PMMA prepared by bulk polymerization was observed: the molecular weight of PMMA extracted from PMMA VB-16 (VB-16 is an organically modified MMT, a cationic clay) was almost double the molecular weight of pristine PMMA and PMMACloisite 10A prepared by bulk polymerization under similar conditions [4]. Wang et al., on the other hand, reported a slight decrease in both the weight average molecular weight $(\mathrm{Mw})$, the number average molecular weight $(M \mathrm{n})$ and an increase in the polydispersity index of the disordered-exfoliated PMMA-undecenoate LDH nanocomposites prepared by bulk polymerization [17]. Their results were attributed to the interference of active sites on the undecenoate-LDH surface that

Thermochimica Acta, Vol. 495, (2009): pg. 63-71. DOI. This article is C Elsevier and permission has been granted for this version to appear in e-Publications@Marquette. Elsevier does not grant permission for this article to be further copied/distributed or hosted elsewhere without the express permission from Elsevier. 
are free radical scavengers and traps [38]. Bourgeat-Lami [39] reviewed the effect of inorganics, clay for example, on the kinetics of multi-phase polymerization of vinyl monomers. The authors indicated that the studies reported so far are highly controversial and pointed out that the nature of the particle surface is a key parameter to understanding the in situ polymerization. The differences observed in the dispersion of the composites, the crystallinity of the additives alone and the different intralayer compositions may explain the various effects of these additives on molecular weights of PMMA. The relatively higher molecular weights observed compared to the virgin polymer suggest that the presence of these additives does not interfere with the polymerization process.

\subsection{Thermal stability of PMMA/LDH composites}

Kashiwagi et al. [40] examined the thermal and oxidative degradation of PMMA prepared by free radical initiators, benzoyl peroxide (BPO) and azo-bis-isobutyronitrile (AIBN). They observed that the nature of the free-radical initiator only slightly affected the degradation mechanism. Accordingly, the rate of degradation is independent of the molecular weight of PMMA [41]. The differences in TGA curves, shown in Fig. 9, can be correlated with the presence of different types of LDH additives in PMMA. In general, the presence of an LDH additive enhances the thermal stability of PMMA, as shown in Fig. 9. At the mid-point temperature of degradation (50\% mass loss), the TGA curves of the composites are shifted to higher temperatures, an indication of improvement in thermal stability. MgAl LDH provides the largest enhancement in thermal stability, a $22^{\circ} \mathrm{C}$ increment when $50 \%$ mass loss is set as the comparison point. CuAl LDH, on the other hand, shows no improvement at $50 \%$ mass loss and a destabilizating effect when $10 \%$ mass loss is set as the point of comparison. The formation of reduced copper species, such as $\mathrm{CuO}$ and $\mathrm{Cu} 2 \mathrm{O}$, at these relatively low processing temperatures may be responsible for the observed destabilization effect of this additive to the polymer.

TGA and FTIR were also performed on the insoluble materials extracted from these composites, as shown in Figs. 10 and 11 and Table 3. Both the pristine polymer and the composites were extracted

Thermochimica Acta, Vol. 495, (2009): pg. 63-71. DOI. This article is (C) Elsevier and permission has been granted for this version to appear in e-Publications@Marquette. Elsevier does not grant permission for this article to be further copied/distributed or hosted elsewhere without the express permission from Elsevier. 
with acetone; the pristine polymer does not leave any insoluble material while the composites left different amount of insoluble materials. This consisted of the LDH along with the polymer polymerized onto the LDH. The weight differences of the insoluble materials and the LDH allow the determination of how much polymer is attached to the LDH. The results are shown in Table 3. Only in the case of CaAl and, to a lesser extent MgAl, does one observe a significant amount of polymer attached to the LDH. For reasons that are not now understood, apparently the double bond of the undecenoate does not participate in the polymerization process for divalent metals other than those of calcium and magnesium. Neither of these is well dispersed, while cobalt, which exhibits the best nanodispersion, does not incorporate any polymer onto the LDH; it seems unlikely that this can be due to dispersion. This is a topic for further investigation.

Fig. 10 compares the TGA profiles of the insoluble materials of PMMA/6\%LDH with both PMMA and LDH ( $\mathrm{LDH}=\mathrm{CaAl}$ or MgAl). These TGA profiles suggest the incorporation of some polymer chains onto the LDH. This was further confirmed by FTIR experiments as shown in Fig. 11; the bands characteristic of LDH-undecenoate are observed (for example, the asymmetric and symmetric stretching of the $\mathrm{COO}^{-}$in $1600-1400 \mathrm{~cm}^{-1}$ region), but also, the absorption peaks of the $\mathrm{C}=\mathrm{O}$ stretching vibration at $1730 \mathrm{~cm}^{-1}$ and $\mathrm{C}-\mathrm{O}$ stretching vibration at $1147 \mathrm{~cm}^{-1}$ confirm the presence of the PMMA. The absorption peak at $1640 \mathrm{~cm}^{-1}$ associated with the $\mathrm{C}=\mathrm{C}$ stretching of the 10-undecenoate anion is not clearly observed, which indicate that the polymerization also occurred on the 10-undecenoate anion bound to the LDH layer surface. Similar results have been previously observed in this laboratory for montmorillonite/PMMA nanocomposites using a surfactant that contained a styryl group [6]. Stronger interactions between an organo-LDH and a PMMA matrix have been reported by Wang et al. who prepared PMMA/LDH nanocomposites using a two-stage process with an in situ bulk polymerization of methyl methacrylate in the presence of 10-undecenoate intercalate-MgAl and observed that the quantity of the recovered PMMA was approximately $79.2 \mathrm{wt} \%$ in the insoluble material [34].

Thermochimica Acta, Vol. 495, (2009): pg. 63-71. DOI. This article is (C) Elsevier and permission has been granted for this version to appear in e-Publications@Marquette. Elsevier does not grant permission for this article to be further copied/distributed or hosted elsewhere without the express permission from Elsevier. 
NOT THE PUBLISHED VERSION; this is the author's final, peer-reviewed manuscript. The published version may be accessed by following the link in the citation at the bottom of the page.

\subsection{Glass transition temperature, $T_{g}$}

The DSC traces of the PMMA/LDHs systems were obtained and the glass transition temperature $\left(T_{\mathrm{g}}\right)$ was determined; the values for the various systems are tabulated in Table 4 . Overall, the presence of LDH does not impact the $T_{\mathrm{g}}$ of the composites, at least not in the range studied. The rather large error bars on $T_{\mathrm{g}}$ suggest that these are not very homogenous materials.

\subsection{Combustion behavior of the PMMA/LDH composites}

Table 5 presents the effects of undecenoate LDH on the flammability of PMMA. Compared to the control sample, greater reductions in PHRR (36\%) are recorded for both PMMA/6\%CaAI LDH and PMMA/6\%NiAl LDH. Overall, the time to ignition and the time to PHRR of the polymer are not affected by the presence of these LDHs. The total heat released is also not changed. It is, however, noted that at these low additive loadings ( 3 and 6\%), these LDHs do not effectively reduce the PHRR of the polymers. Previous work on this polymer showed that reduction of about $50 \%$ can be obtained if the loading of MgAl or CoAl LDHs is $10 \%$. The advantage of using a lower loading is that one is more likely to maintain the mechanical properties of the polymer.

The current results should be compared with previous work on melt blended PMMA/LDH systems. The PMMA/6\%ZnAl system in this study gave $16 \%$ reduction in PHRR relative to pristine polymer; this result compares well with previous reported data where a melt blended PMMA/5\%ZnAl gave 18\% [29]. A better interaction of LDH with PMMA matrix can be obtained by preparing PMMA/LDH systems in two stages: a pre-polymerization step followed by a polymerizationcasting. In fact, in earlier work on PMMA/ZnAl systems, PMMA/5\% ZnAl prepared by two-step in situ polymerization gave 33\% reduction in PHRR relative to the control sample prepared under similar conditions [42]. It has been observed that the PMMA/LDH composites prepared by either method are more thermal stable relative to the control samples. The experimental procedure for a two-stage in situ polymerization process is more complex but more effectively leads to materials with reduced flammability. Promising results were obtained

Thermochimica Acta, Vol. 495, (2009): pg. 63-71. DOI. This article is (C) Elsevier and permission has been granted for this version to appear in e-Publications@Marquette. Elsevier does not grant permission for this article to be further copied/distributed or hosted elsewhere without the express permission from Elsevier. 
with PMMA modified with a series of MgAl-alkyl carboxylate LDHs by melt blending methodology; reductions in PHRR greater than $40 \%$ were obtained at $5 \%$ LDH loading [22]. The efficacy of PMMA/6\%NiAl and $\mathrm{PMMA} / 6 \% \mathrm{CaAl}$ samples reveal new key information concerned with the understanding of the mechanism of action of these additives. Dispersion is important, but it is not the only factor, considering the larger reductions in PHRR (36\% for both systems) relative to the other composites. In fact, the TEM images reveal poor dispersion and agglomerates of LDH particulates are visible, but these samples performed surprisingly well in the cone calorimeter experiments. The systems should be characterized as microcomposites; no evidence of entrance of polymer between the layers of the LDH is observed. It is likely that a beneficial polymer-LDH agglomerate interaction is responsible for the efficacy of nickel and calcium containingcomposites in the cone calorimetric experiments.

\section{Conclusions}

PMMA/LDH composites where the LDH trivalent metal cation is aluminum, the charge balancing anion is undecenoate and the divalent metal cations are varied from $\mathrm{Mg}, \mathrm{Ca}, \mathrm{Ni}, \mathrm{Co}, \mathrm{Cu}$ and $\mathrm{Zn}$ were successfully synthesized by in situ bulk polymerization. The TGA results suggest that the presence of an $\mathrm{LDH}$ enhances the thermal stability of the composites relative to the pristine polymer. The glass transition temperature is not affected by the presence of these additives suggesting no change in chain mobility for the composites. PMMA/6\%NiAl and PMMA/6\%CaAl LDH give the largest reductions in the peak heat release rate, yet they are definitely microcomposites. A poorly dispersed LDH is capable of bringing about a significant enhancement in fire properties; this is in contrast to what has been obtained for montmorillonite and suggests that the mechanism by which the flammability is reduced is different for the two nanomaterials.

Acknowledgments: This work was performed under the sponsorship of the US Department of Commerce, National Institute of Standards and Technology, Grant 60NANB6D6018. We thank Dr. David Berzins for the use of the DSC and useful discussion on the interpretation of the glass transition temperature data. We also thank Emily Skibinski, a summer student in the laboratory, for work on the DSC.

Thermochimica Acta, Vol. 495, (2009): pg. 63-71. DOI. This article is (C) Elsevier and permission has been granted for this version to appear in e-Publications@Marquette. Elsevier does not grant permission for this article to be further copied/distributed or hosted elsewhere without the express permission from Elsevier. 
NOT THE PUBLISHED VERSION; this is the author's final, peer-reviewed manuscript. The published version may be accessed by following the link in the citation at the bottom of the page.

About the Authors: Corresponding author. Tel.: +1 414288 7065; fax: +1 414288 7066. E-mail address: charles.wilkie@marquette.edu (C.A. Wilkie).

\section{References}

[1] C. Zeng, L. Lee, J. Macromol. 34 (2001) 4098.

[2] E. Manias, A. Touny, L. Wu, K. Strawhecker, B. Lu, T.C. Chung, Chem. Mater. 13 (2001) 3516.

[3] Y.K. Kim, Y.S. Choi, K.H. Wang, I.J. Chung, Chem. Mater. 14 (2002) 4990.

[4] D. Wang, J. Zhu, Q. Yao, C.A. Wilkie, Chem. Mater. 14 (2002) 3837.

[5] F.M. Uhl, C.A. Wilkie, Polym. Degrad. Stab. 76 (2002) 111.

[6] S. Su, C.A. Wilkie, J. Polym. Sci. Polym. Chem. 41 (2003) 1124.

[7] J.M. Yeh, S.J. Liou, C.Y. Lin, C.Y. Cheng, Y.W. Chang, Chem. Mater. 22 (2002) 1306.

[8] J.W. Gilman, T. Kashiwagi, M. Nyden, J.E.T. Brown, C.L. Jackson, S. Lomakin, E.P. Giannelis, E. Manias, in: S. Al-Malaika, A. Golovoy, C.A. Wilkie (Eds.), Chemistry and Technology of Polymer Additives, Blackwell Scientific, Oxford, 1999, pp. 249-265.

[9] S. Bourbigot, M. Le Bras, F. Dabrowski, J.W. Gilman, T. Kashiwagi, J. Fire Sci. 19 (2001) 219.

[10] J. Zhu, F.M. Uhl, A.B. Morgan, C.A. Wilkie, Chem. Mater. 13 (2001) 4649.

[11] J. Zhu, P. Start, K.A. Mauritz, C.A. Wilkie, Polym. Degrad. Stab. 77 (2002) 253.

[12] F. Leroux, C.J. Taviot-Guého, Mater. Chem. 15 (2005) 3628.

[13] G.R. Williams, D.J. O'Hare, Mater. Chem. 16 (2006) 3065.

[14] D.G. Evans, X. Duan, Chem. Commun. 485 (2006) 485

[15] F. Cavani, F. Trifiro, A. Vaccari, Catal. Today 11 (1991) 173.

[16] B.B. Kine, R.W. Novak, Acrylic and methacrylic ester polymers, in: H.F. Mark, N.M. Bikales, C.G. Overberger, G. Menges, Kroschwitz (Eds.), Encyclopedia of Polymer Science and Engineering, vol. 1, 2nd ed., Wiley, New York, 1985, p. 262.

[17] G.A. Wang, C.C. Wang, C.Y. Chen, Polym. Degrad. Stab. 91 (2006) 2443.

[18] Y.Z. Bao, Z.M. Huang, Z.X. Weng, J. Appl. Polym. Sci. 102 (2006) 1471.

[19] W. Chen, B. Qu, Chem. Mater. 15 (2003) 3208.

[20] W. Chen, L. Feng, B. Qu, Chem. Mater. 16 (2004) 368.

[21] C. Manzi-Nshuti, D. Wang, J.M. Hossenlopp, C.A. Wilkie, J. Mater. Chem. 18 (2008) 3091.

[22] C. Nyambo, P. Songtipya, E. Manias, M.M. Jimenez-Gasco, C.A. Wilkie, J. Mater. Chem. 18 (2008) 4827.

Thermochimica Acta, Vol. 495, (2009): pg. 63-71. DOI. This article is (C) Elsevier and permission has been granted for this version to appear in e-Publications@Marquette. Elsevier does not grant permission for this article to be further copied/distributed or hosted elsewhere without the express permission from Elsevier. 
[23] M. Zammarano, M. Franceschi, S. Bellayer, J.W. Gilman, S. Meriana, Polymer 47 (2006) 652

[24] W. Hergeth, U. Steinau, H. Bittrich, G. Simon, K. Schmutzler, Polymer 30 (1989) 254.

[25] J.Q. Pham, C.A. Mitchell, J.L. Bahr, J.M. Tour, R. Krishanamoorti, P.F. Green, J. Polym. Sci. Part B: Polym. Phys. 41 (2003) 3339.

[26] B.J. Ash, L.S. Schadler, R.W. Siegel, Mater. Lett. 55 (2002) 83.

[27] S.C. Glotzer, W. Paul, Annu. Rev. Mater. Res. 32 (2002) 401.

[28] Y. Sun, Z. Zhang, K. Moon, C.P. Wong, J. Polym. Sci. Part B: Polym. Phys. 42 (2004) 3849.

[29] C. Manzi-Nshuti, J.M. Hossenlopp, C.A. Wilkie, J. Mater. Chem. 18 (2008) 3091.

[30] T. Hibino, Chem. Mater. 16 (2004) 5482.

[31] M. Kurata, Y. Tsunashima, in: J. Immergut, E.H. Grulke, E.A. Brandrup (Eds.), Polymer Handbook, 4th ed., Wiley, New York, 1999, p VII, 183.

[32] J.W. Gilman, T. Kashiwagi, M. Nyden, J.E.T. Brown, C.L. Jackson, S. Lomakin, E.P. Giannelis, E. Manias, in: S. Al-Malaika, A. Golovoy, C.A. Wilkie (Eds.), Chemistry and Technology of Polymer Additives, Blackwell Scientific, Oxford, 1999, p. 249.

[33] R. Jenkins, R.L. Synder, Introduction to X-ray Powder Diffractometry, Wiley, New York, 1996.

[34] G.-A. Wang, C.C. Wang, C.Y. Chen, Polymer 46 (2005) 5065.

[35] K.M. McGrath, Colloid. Polym. Sci. 274 (1996) 499.

[36] M. Taibi, S. Ammar, N. Jouini, F. Fiëvet, P. Molinié, M. Drillon, J. Mater. Chem. 12 (2002) 3238.

[37] Z.P. Xu, H.C. Zeng, J. Phys. Chem. B 104 (2000) 10206.

[38] G.A. Wang, C.C. Wang, C.Y.J. Chen, Inorg. Organomet. Polym. 15 (2005) 239.

[39] E. Bourgeat-Lami, Organic-inorganic nanocomposites by multiphase polymerization, in: R. Arshady, A. Guyot (Eds.), Dendrimers, Assemblies and Nanocomposites, vol. 5, Citus Book, London, 2002, pp. 149-194 (Chapter 5).

[40] T. Kashiwagi, A. Inaba, J.E. Brown, K. Hatada, T. Kitayama, E. Masuda, Molecules 19 (1986) 2160.

[41] R.H. Boyd, in: R.T. Conley (Ed.), Thermal Stability of Polymers, Marcel Dekker, New York, 1970.

[42] C. Manzi-Nshuti, J.M. Hossenlopp, C.A. Wilkie, Polym. Degrad. Stab. 93 (2008) 1855.

Thermochimica Acta, Vol. 495, (2009): pg. 63-71. DOI. This article is (C) Elsevier and permission has been granted for this version to appear in e-Publications@Marquette. Elsevier does not grant permission for this article to be further copied/distributed or hosted elsewhere without the express permission from Elsevier. 
NOT THE PUBLISHED VERSION; this is the author's final, peer-reviewed manuscript. The published version may be accessed by following the link in the citation at the bottom of the page.

\section{Appendix}

\section{Table 1}

Interlayer spacings and the crystallite sizes of the various undecenoate-LDHs.

\begin{tabular}{llll}
\hline Material & $2 \theta$ & d-spacing $(\mathrm{nm})$ & Crystallite size $(\mathrm{nm})$ \\
\hline NiAl & 3.5 & 2.5 & 10 \\
MgAl & 3.9 & 2.3 & 9 \\
CaAl & 2.8 & 3.2 & 63 \\
CoAl & 3.8 & 2.3 & 11 \\
ZnAl & 2.9 & 3.0 & 14 \\
CuAl & 3.1 & 2.8 & 13
\end{tabular}

Note: Average crystallite sizes were determined using the DebyeScherrer equation: $\mathrm{T}=\mathrm{\kappa} N\left(\beta_{\mathrm{T}} \cos \theta\right)$ where $\mathrm{\kappa}$ is a constant $(0.9$ for powders [33]), $\beta_{\mathrm{T}}$ is the full width at half maximum height of a

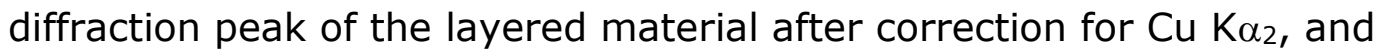

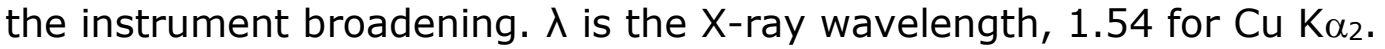
The instrument response was obtained using the National Institute of Standards and Technology (NIST) standard reference material Si powder (SRM 640C).

\section{Table 2}

\section{Molecular weights from viscosity measurements.}

\begin{tabular}{lll}
\hline Material & MW & (Stdev) \\
\hline PMMA (0.1\%AIBN) & 16,4000 & 4000 \\
PMMA 6\%CaAl LDH & 349,000 & 7000 \\
PMMA 6\%MgAl LDH & 210,000 & 7000 \\
PMMA 6\%NiAl LDH & 257,000 & 9000 \\
\hline
\end{tabular}

Thermochimica Acta, Vol. 495, (2009): pg. 63-71. DOI. This article is (C) Elsevier and permission has been granted for this version to appear in e-Publications@Marquette. Elsevier does not grant permission for this article to be further copied/distributed or hosted elsewhere without the express permission from Elsevier. 
NOT THE PUBLISHED VERSION; this is the author's final, peer-reviewed manuscript. The published version may be accessed by following the link in the citation at the bottom of the page.

\section{Table 3}

Recovery of the polymer attached to the LDH for PMMA nanocomposites.

\begin{tabular}{lcl}
\hline Composite & Insoluble material $(\%)$ & $\%$ of polymer attached to the LDH \\
\hline PMMA/6\% & 6 & 0 \\
PMMAl $/ 6 \% \mathrm{ZnAl}$ & 8 & 2 \\
PMMA/6\%CoAl & 7 & 1 \\
PMMA/6\%CuAl & 6 & 0 \\
PMMA/6\%MgAl & 9 & 3 \\
PMMA/6\%CaAl & 14 & 8 \\
\hline
\end{tabular}

Note: The \% of polymer attached to the $\mathrm{LDH}=\%$ mass recovered polymer/LDH after extraction with acetone (insoluble material) - \% $\mathrm{LDH}$ loading used in this investigation (6\%).

Table 4

Glass transition temperatures of various PMMA/LDH systems.

Material $T_{\mathrm{g}}\left({ }^{\circ} \mathrm{C}\right)$

PMMA, 0.1\% AIBN

$117.0 \pm 1.0$

PMMA, 0.2\% AIBN

$109.5 \pm 2.8$

PMMA, 0.4\% AIBN

$111.0 \pm 3.6$

PMMA, 6\% CaAl

$114.4 \pm 2.3$

PMMA, 6\% MgAl

$111.5 \pm 1.4$

PMMA, 6\% ZnAl

$109.3 \pm 1.4$

PMMA, 6\% NiAl

$107.7 \pm 0.9$

PMMA, $6 \%$ CuAl

$114.5 \pm 2.2$

PMMA, 6\% CoAl

$116.8 \pm 1.6$

Thermochimica Acta, Vol. 495, (2009): pg. 63-71. DOI. This article is (C) Elsevier and permission has been granted for this version to appear in e-Publications@Marquette. Elsevier does not grant permission for this article to be further copied/distributed or hosted elsewhere without the express permission from Elsevier. 
NOT THE PUBLISHED VERSION; this is the author's final, peer-reviewed manuscript. The published version may be accessed by following the link in the citation at the bottom of the page.

\section{Table 5}

Cone calorimetric summary results of PMMA/LDHs composites at $50 \mathrm{k} \mathrm{W} / \mathrm{m} 2$.

\begin{tabular}{|c|c|c|c|c|c|}
\hline Femalation & PHKR (kW/m² (z) red!) & then (s) & $\operatorname{THa}\left(\mathrm{M} / \mathrm{m}^{2}\right)$ & AMILE $\left(2 \tan ^{2} 3\right)$ & $\tan \langle 3\rangle$ \\
\hline PMMA, 0.5 AMEN & $94 \pm 14(n)$ & $84 \pm 4$ & $74 \pm 3$ & $209 \pm 68$ & $11 \pm 0.6$ \\
\hline PAMM, 0.28, Nilis & 971 \& $28 \mathrm{na}$ & $\$ 5=3$ & $n+1$ & $311=04$ & $8 \div 0.8$ \\
\hline 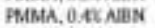 & $981 \pm 30(\mathrm{na})$ & $33=5$ & $78 \pm 1$ & $32.3 \pm 0.6$ & $8 \pm 0.8$ \\
\hline DMMM, 3 × Cal & $656+40(27)$ & 901 & $75+1$ & $23.9+0.6$ & $8+14$ \\
\hline PAIMA.6xCaAl & $602=22(36)$ & $106=4$ & $35 \pm 2$ & $21.3 \pm 0.7$ & $11=13$ \\
\hline FAMA, 32 $\mathrm{MeN}$ & $8 \pi 5=104[7]$ & $85=10$ & $n+1$ & $28.4 \pm 1.3$ & $8 \pm 14$ \\
\hline คAMMA, $65 \mathrm{MeN}$ & $m_{1}=\pi(24$ & $100+7$ & $78 \pm 5$ & $247 \pm 17$ & $14 \pm 04$ \\
\hline PMPM, $32 \mathrm{ZnN}$ & $82 x+30(12)$ & $91=7$ & $\pi=5$ & 213009 & $8 \leqslant 11$ \\
\hline FMMA , 6E ZRN & $769+48(15)$ & $9=1$ & $n \neq 1$ & $2 S: B=0 A$ & $9 \pm 01$ \\
\hline 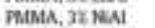 & $898+41$ [5] & $85: 4$ & $79+3$ & $297+11$ & $11+15$ \\
\hline TMMМ, 6X NENI & $607+x(36)$ & $m=n$ & $78+4$ & $212+15$ & $10 \pm 16$ \\
\hline FMMMA, 32 Cad & $939 \pm \pi 70$ & $9=1$ & $32 \pm 4$ & $29.8=11$ & $10 \pm 1.7$ \\
\hline РMMA, 6xсти। & $900+29<0 \%$ & $84+3$ & $85+3$ & $287 \pm 07$ & $8 \pm 10$ \\
\hline FaMM, 3LCon & $100 \div \pi(0)$ & $90=2$ & $80+3$ & $346=21$ & $11=18$ \\
\hline PMMA , FX. CoN & $x+1-77(7)$ & $9=9$ & $9+7$ & $261+04$ & $12+18$ \\
\hline
\end{tabular}

Note: PHRR, peak heat release rate; $t_{\mathrm{PHRR}}$, time to PHRR; THR, total heat released; AMLR, average mass loss rate; $t_{\text {ign, }}$ time-to-ignition.

Figure 1

XRD patterns of the undecenoate-containing LDHs of MgAl, NiAl, CoAl, CuAl and ZnAl.

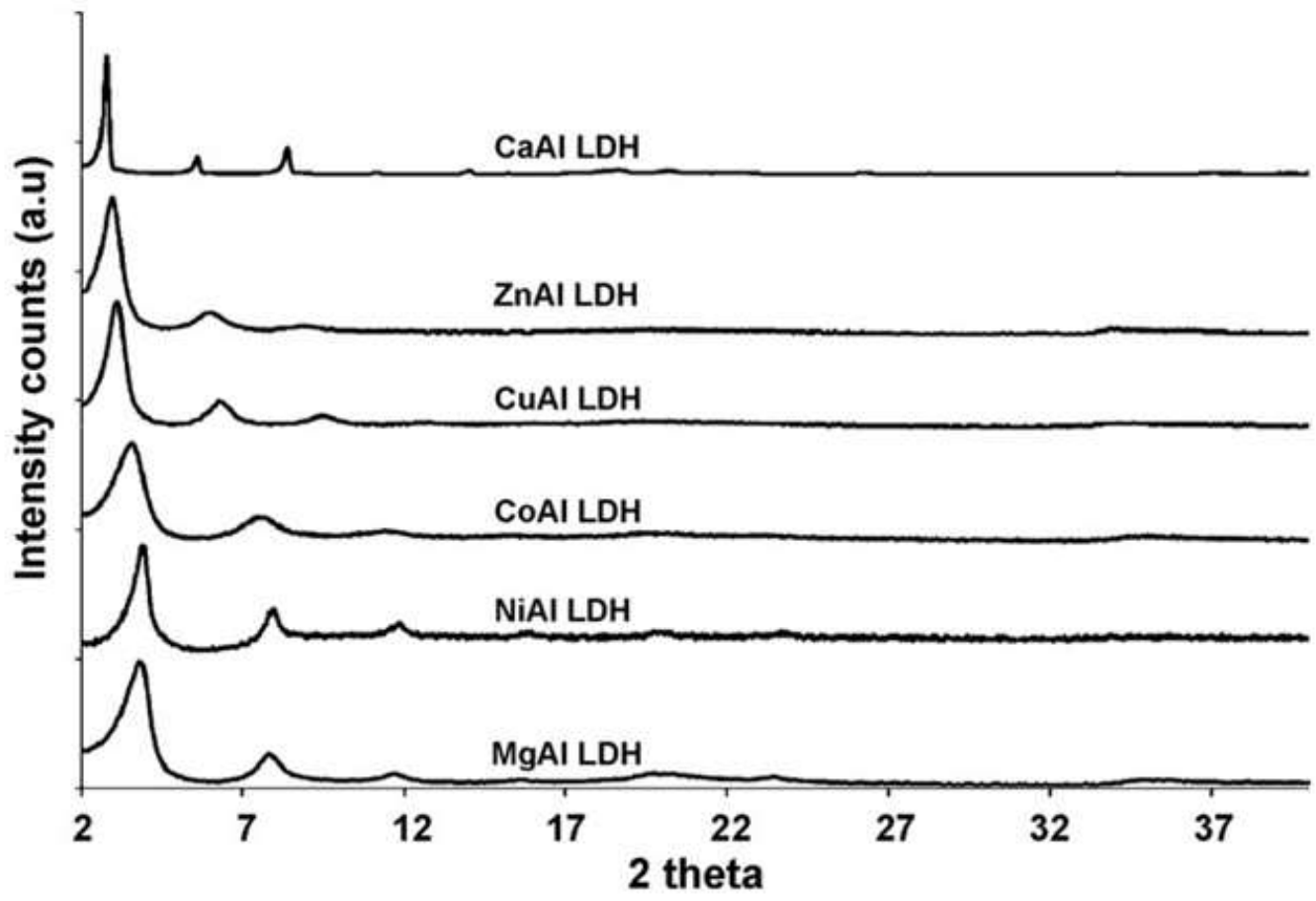

Thermochimica Acta, Vol. 495, (2009): pg. 63-71. DOI. This article is C Elsevier and permission has been granted for this version to appear in e-Publications@Marquette. Elsevier does not grant permission for this article to be further copied/distributed or hosted elsewhere without the express permission from Elsevier. 
NOT THE PUBLISHED VERSION; this is the author's final, peer-reviewed manuscript. The published version may be accessed by following the link in the citation at the bottom of the page.

\section{Figure 2}

IR spectra of the undecenoate-containing LDHs of MgAl, NiAl, CoAl, CuAl and ZnAl.

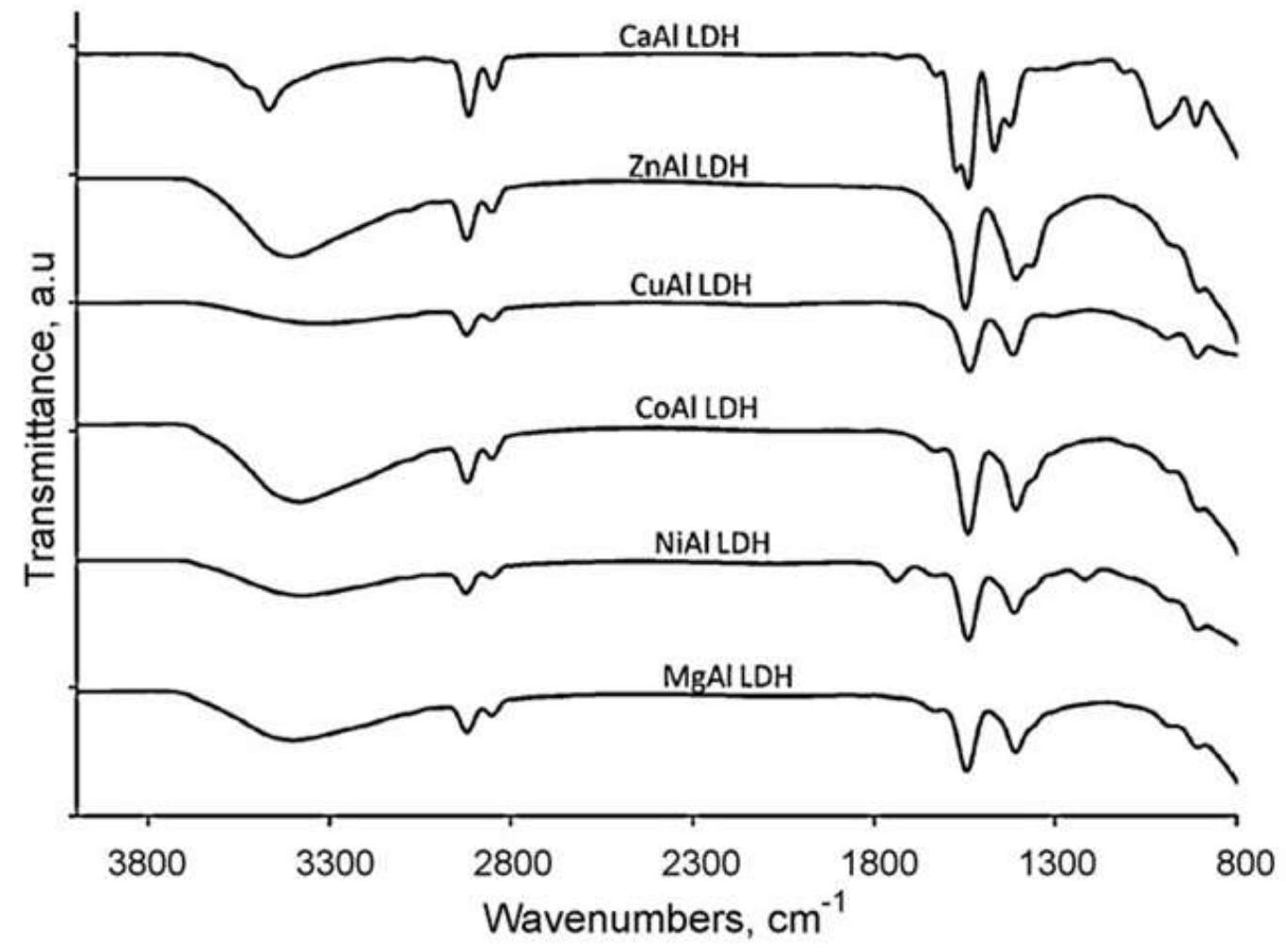

Thermochimica Acta, Vol. 495, (2009): pg. 63-71. DOI. This article is C Elsevier and permission has been granted for this version to appear in e-Publications@Marquette. Elsevier does not grant permission for this article to be further copied/distributed or hosted elsewhere without the express permission from Elsevier. 
NOT THE PUBLISHED VERSION; this is the author's final, peer-reviewed manuscript. The published version may be accessed by following the link in the citation at the bottom of the page.

Figure 3

IR spectra of the undecenoate-containing LDHs (*) (after Soxhlet extraction with acetone for 2 days) of MgAl, NiAl, CoAl, CuAl and ZnAl.

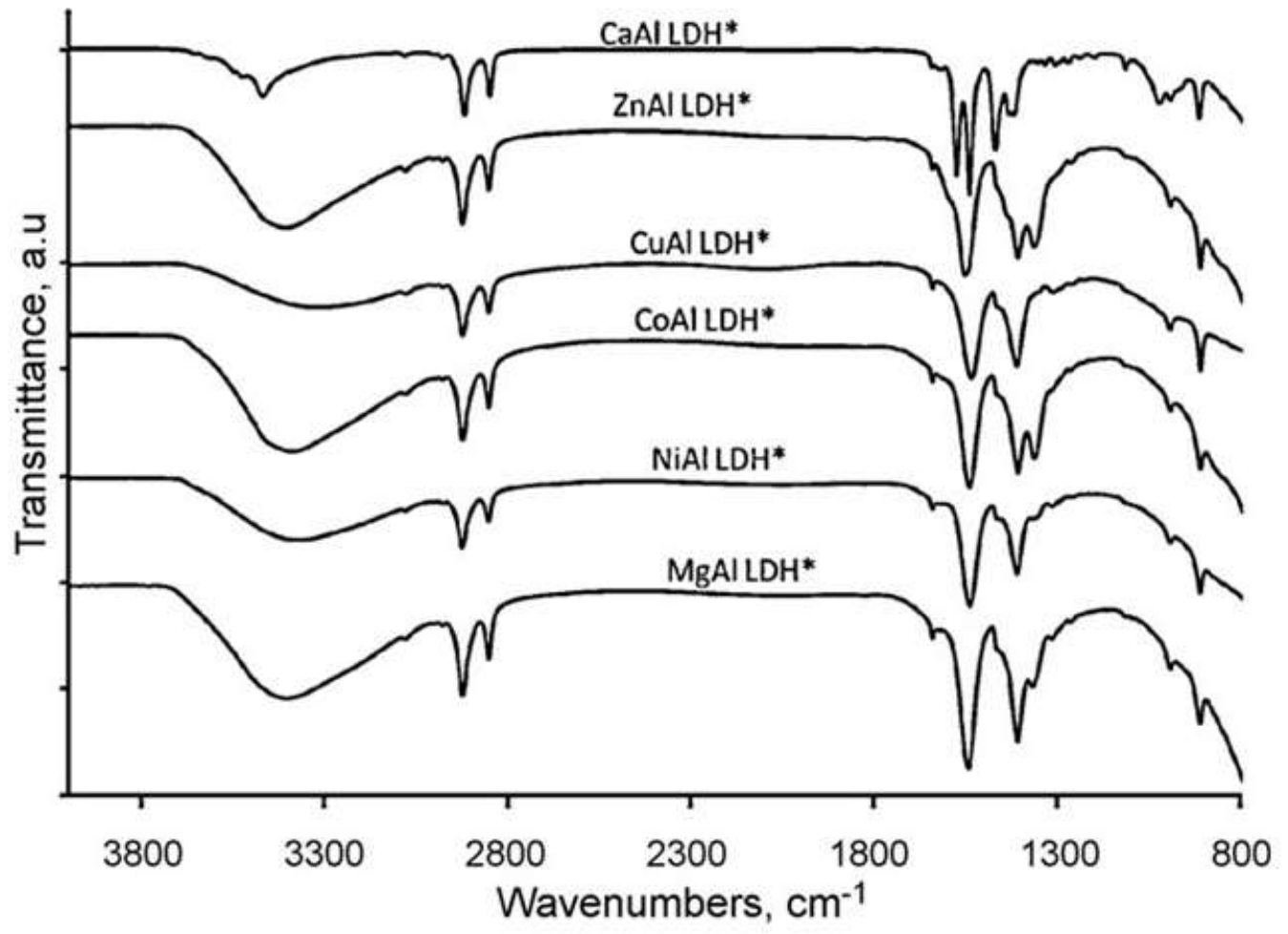

Figure 4

TGA curves of undecenoate-LDHs in air environment at 20 ${ }^{\circ} \mathrm{C} / \mathrm{min}$ from 30 to $800{ }^{\circ} \mathrm{C}$.

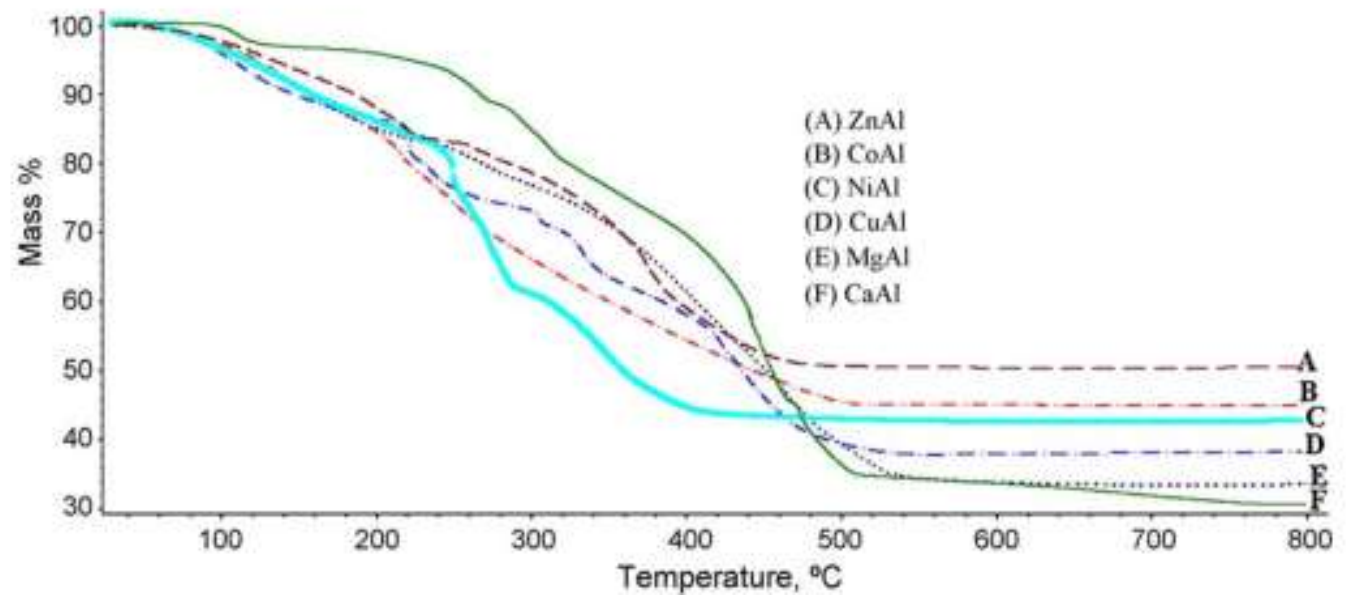

Thermochimica Acta, Vol. 495, (2009): pg. 63-71. DOI. This article is (C) Elsevier and permission has been granted for this version to appear in e-Publications@Marquette. Elsevier does not grant permission for this article to be further copied/distributed or hosted elsewhere without the express permission from Elsevier. 
NOT THE PUBLISHED VERSION; this is the author's final, peer-reviewed manuscript. The published version may be accessed by following the link in the citation at the bottom of the page.

\section{Figure 5}

TGA curves in air of undecenoate-LDHs before and after washing LDHs in a Soxhlet extraction apparatus with acetone for 2 days.
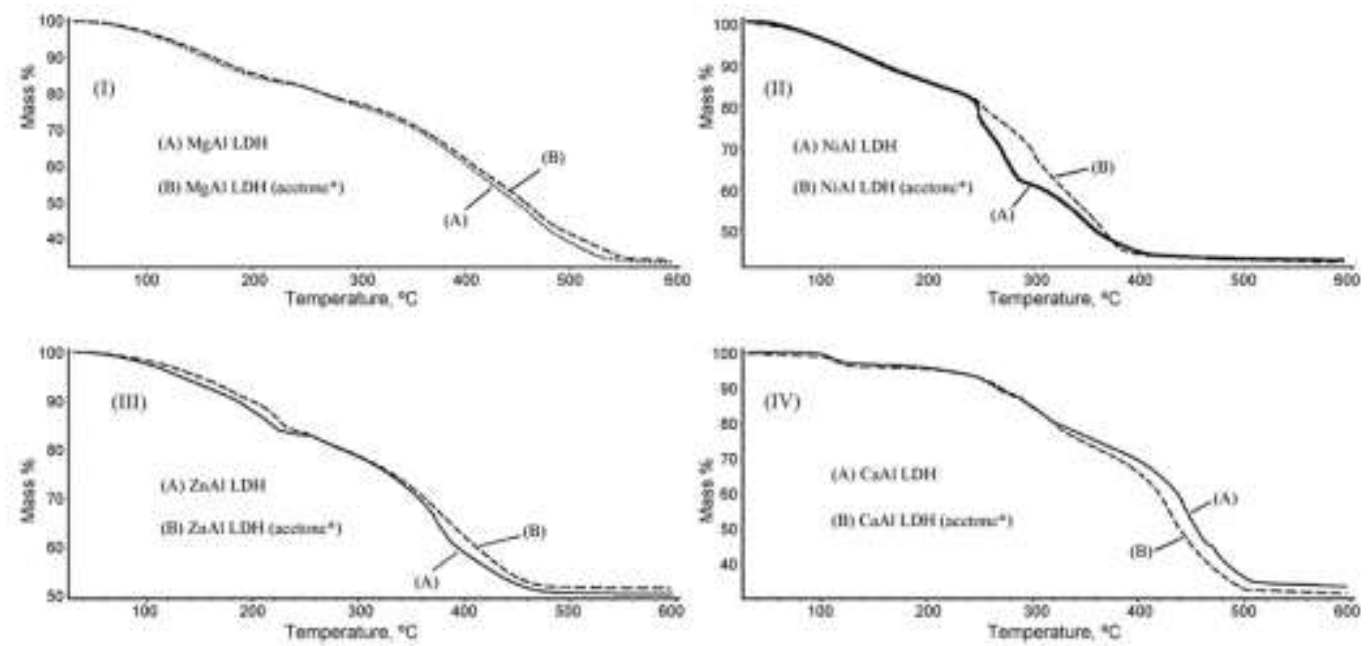

Thermochimica Acta, Vol. 495, (2009): pg. 63-71. DOI. This article is C Elsevier and permission has been granted for this version to appear in e-Publications@Marquette. Elsevier does not grant permission for this article to be further copied/distributed or hosted elsewhere without the express permission from Elsevier. 
NOT THE PUBLISHED VERSION; this is the author's final, peer-reviewed manuscript. The published version may be accessed by following the link in the citation at the bottom of the page.

\section{Figure 6}

\section{XRD traces of various PMMA/LDH systems, loadings of 3 and 6\%. (A)PMMA/MgAl; (B) PMMA/ZnAl; (C) PMMA/CuAl; (D) PMMA/CaAl; (E) PMMA/NiAl and (F) PMMA/CoAl.}
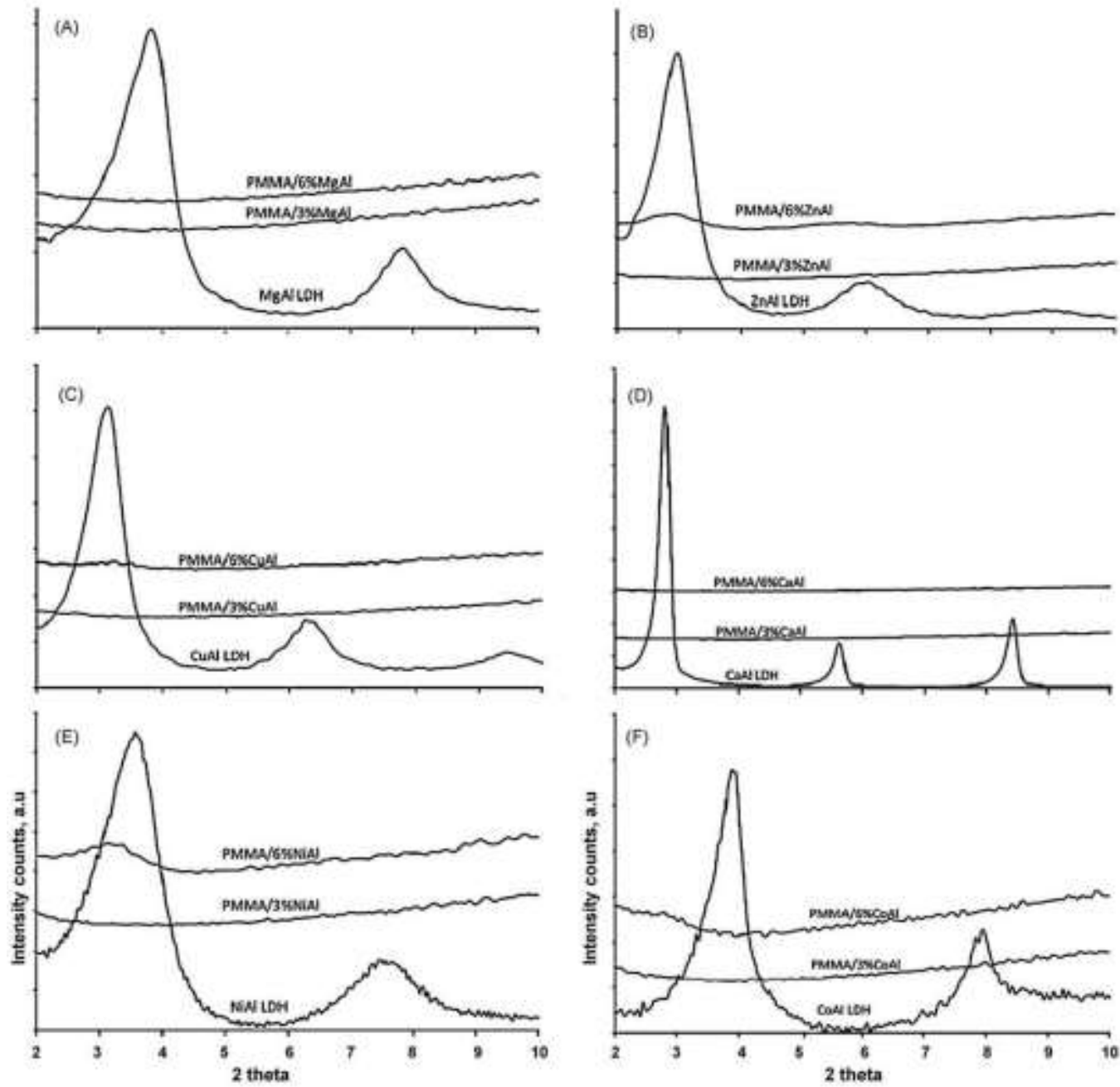

Thermochimica Acta, Vol. 495, (2009): pg. 63-71. DOI. This article is (C) Elsevier and permission has been granted for this version to appear in e-Publications@Marquette. Elsevier does not grant permission for this article to be further copied/distributed or hosted elsewhere without the express permission from Elsevier. 
NOT THE PUBLISHED VERSION; this is the author's final, peer-reviewed manuscript. The published version may be accessed by following the link in the citation at the bottom of the page.

\section{Figure 7}

TEM images of PMMA/LDH systems at low magnification. (A) PMMA/3\%NiAl; (B) PMMA/3\%MgAl; (C) PMMA/3\%CoAl; (D) PMMA/3\%CaAl; (E) PMMA/3\%CuAl.

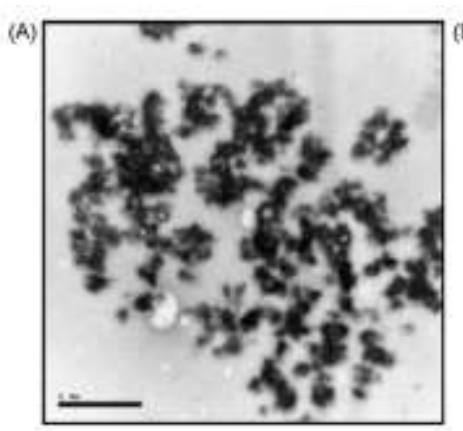

(D)
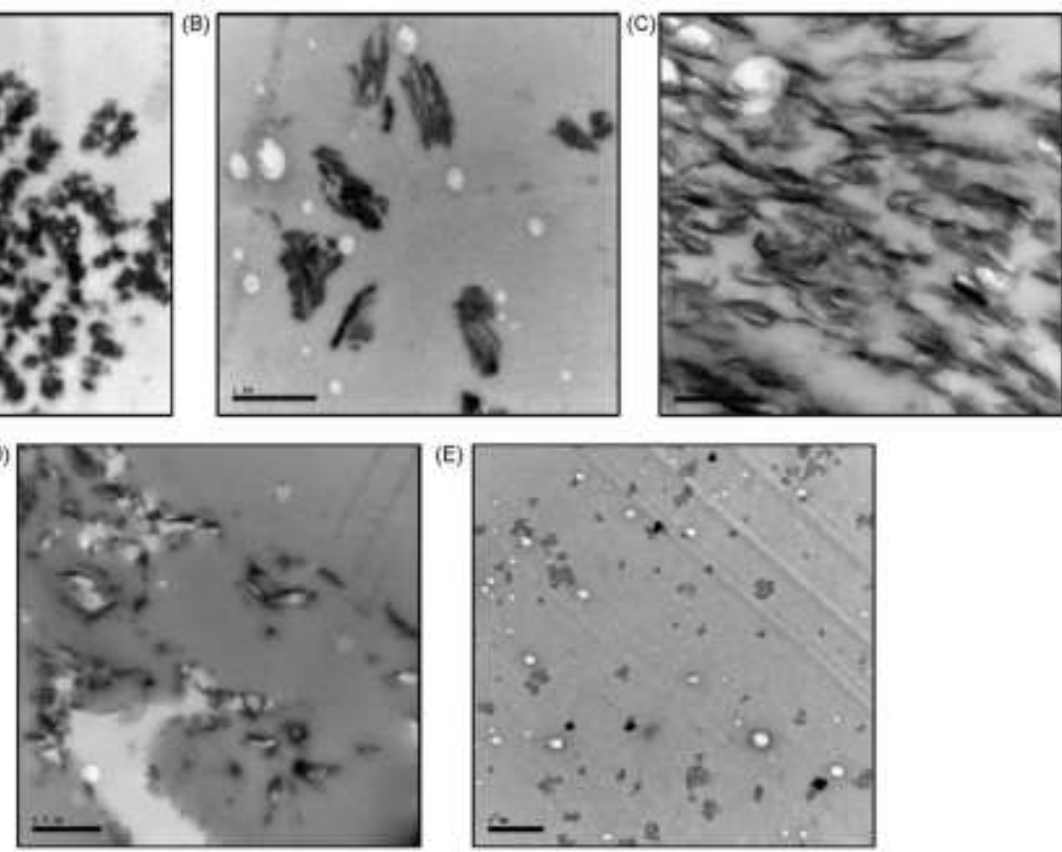

Thermochimica Acta, Vol. 495, (2009): pg. 63-71. DOI. This article is (C) Elsevier and permission has been granted for this version to appear in e-Publications@Marquette. Elsevier does not grant permission for this article to be further copied/distributed or hosted elsewhere without the express permission from Elsevier. 
NOT THE PUBLISHED VERSION; this is the author's final, peer-reviewed manuscript. The published version may be accessed by following the link in the citation at the bottom of the page.

\section{Figure 8}

TEM images of PMMA/LDH systems at high magnification. (A)

PMMA/3\%NiAl; (B) PMMA/3\%MgAl; (C) PMMA/3\%CoAl; (D)

PMMA/3\%CaAl; (E) PMMA/3\%CuAl.
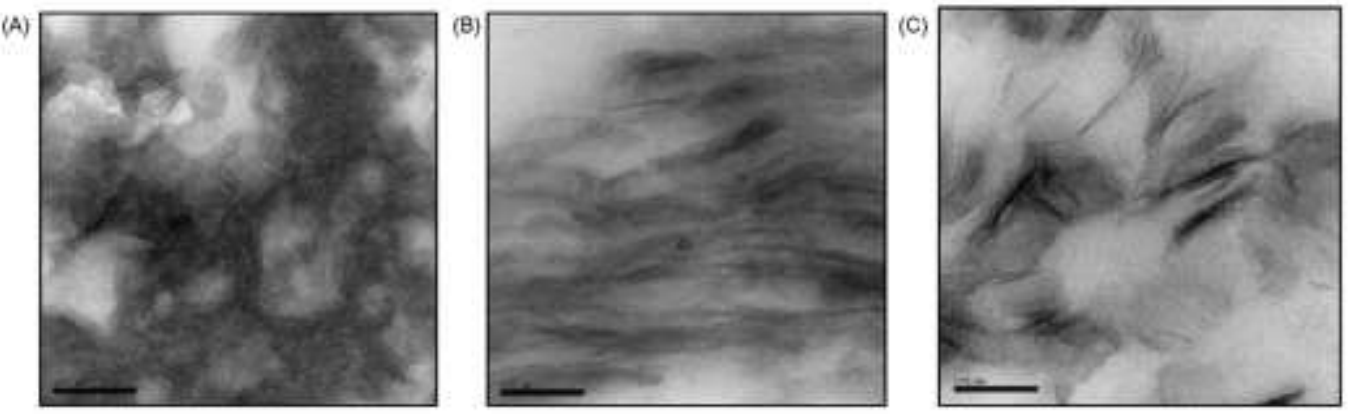

(D)
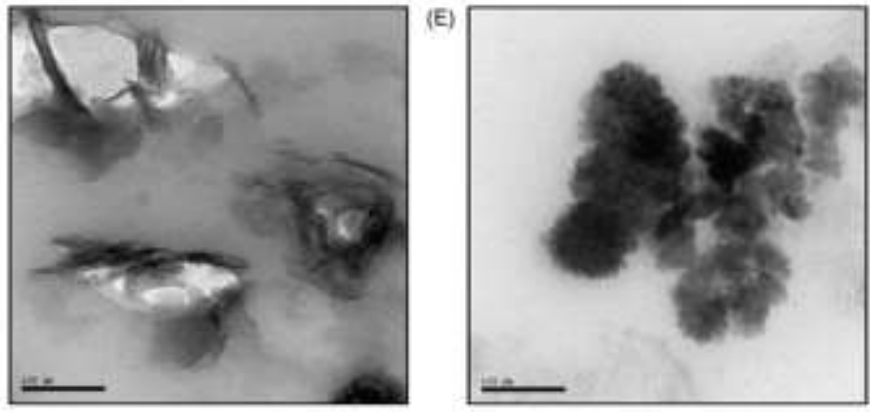

Figure 9

TGA curves of PMMA and its LDH composites at $6 \%$ additive (wt\%) loading.

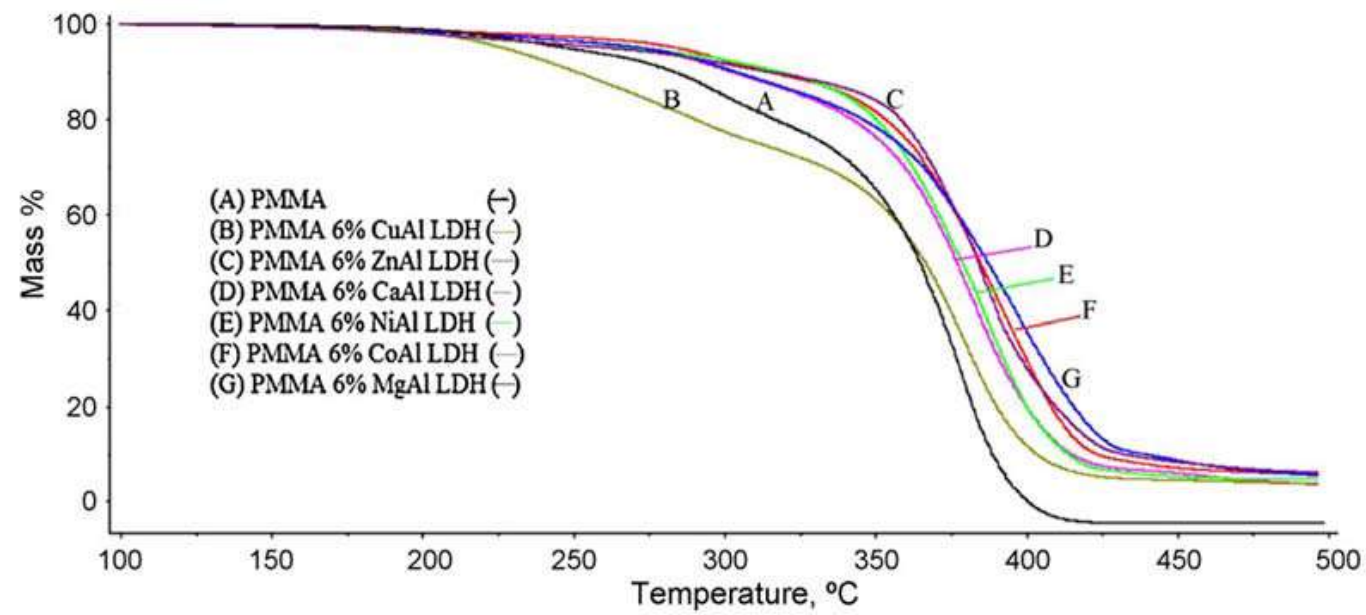

Thermochimica Acta, Vol. 495, (2009): pg. 63-71. DOI. This article is (C) Elsevier and permission has been granted for this version to appear in e-Publications@Marquette. Elsevier does not grant permission for this article to be further copied/distributed or hosted elsewhere without the express permission from Elsevier. 
Figure 10

Comparative TGA profiles of (I) CaAl and (II) MgAl in nitrogen environment at $20^{\circ} \mathrm{C} / \mathrm{min}$ of pristine: PMMA (A), insoluble PMMA /6\%LDH after extraction with acetone and (C) LDH.
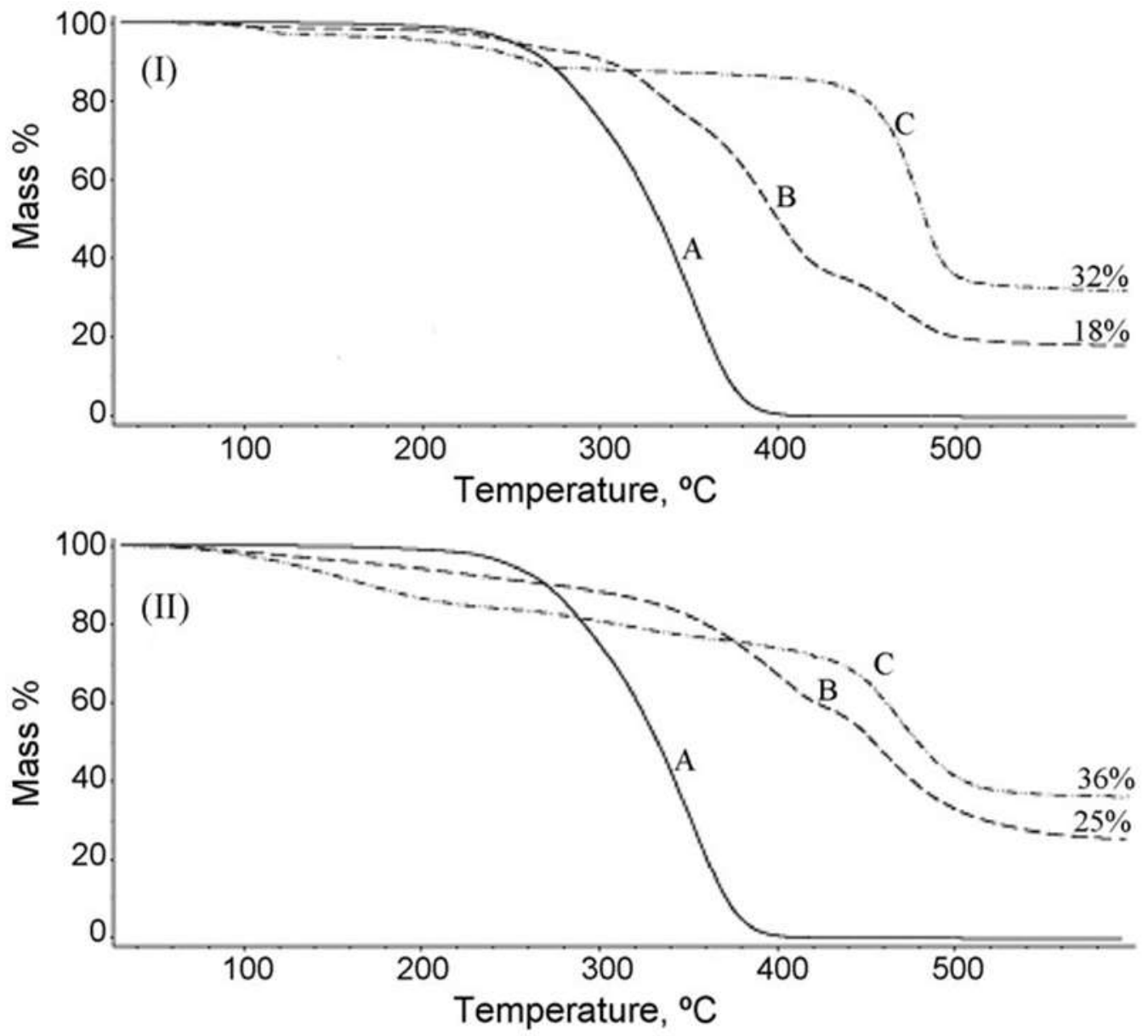
NOT THE PUBLISHED VERSION; this is the author's final, peer-reviewed manuscript. The published version may be accessed by following the link in the citation at the bottom of the page.

Figure 11

FT-IR spectra of insoluble materials of (A) PMMA/6\% MgAl and (B) PMMA/6\%CaAl after extraction with the acetone.

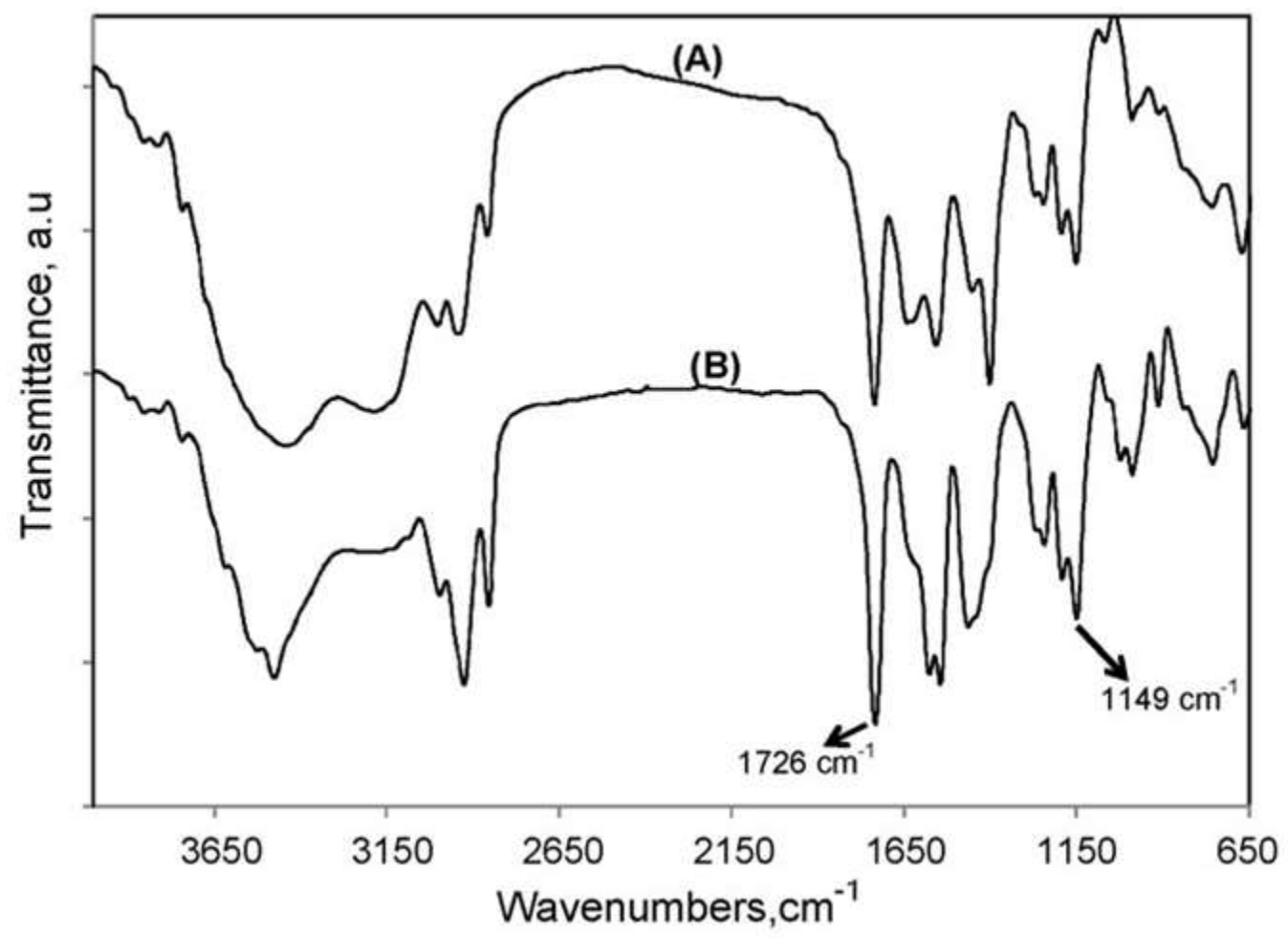

Thermochimica Acta, Vol. 495, (2009): pg. 63-71. DOI. This article is C Elsevier and permission has been granted for this version to appear in e-Publications@Marquette. Elsevier does not grant permission for this article to be further copied/distributed or hosted elsewhere without the express permission from Elsevier. 